\title{
The Industrial Need of Technically Trained Men
}

\author{
The Career of Marine Engineering
}

\section{By J. C. Workman}

Mr. J. C. Workman, the author of the following article, is Chief Engineer of the American Shipbuilding Company. He began work in the machine shop of the William Cramp Ship and Engine Company, at Philadelphia, some 26 years ago. From gang foreman in the shop for 2 years, he went into the drafting room of the engineering department.

In 1897, he went to Cleveland to work on revenue cutters for the Globe Iron Works, of which he was made chief draftsman a year later. When the American Shipbuilding Company was formed in 1899, taking over several companies, including the Globe Iron Works, he was made chief draftsman of the combination. In 1911, he was made its chief engineer.

Mr. Workman obtained his technical education at Franklin Institute, Philadelphia. He is a member of the Cleveland Engineering Society.-EDiror.

THE question as to whether a college education is essential in marine engineering has been very thoroughly discussed by Messrs. Carnegie and Crane. My own opinion, after some 26 years in the business, is that it all depends upon the man. However, the man with the college education will make more rapid progress, than the man who, after his days work is over, has to grind over his books with a tired brain. The company with which I am associated always shows a preference for college men, or at least boys with manual training experience.

However much experience the so-called self made or practical man may possess, he is constantly compelled to consult the scientific or college man, on many difficult and perplexing problems which ean only be worked out by the technically trained mind.

The marine engineer must naturally have a mechanical mind. He should have an analytical mind, and be able to reason out cause and effect. He should cultivate the power of observation and concentration and must posses a good memory. This is most essential. He must have courage, as often he will have to accept great responsibilities, involving large undertakings that may stand or fall, depending upon his engineering ability.

Often he is compelled to attempt new feats in engineering for which he can find no precedent or data in the text books, but must use his own ideas, based on common sense and experience. This remainds me that one of the most prominent marine engineers of the East once remarked: "Never let your engineering get away with your common sense. Engineering is only common sense."

From the crude little "Clermont," of 1807, called "Fulton's Folly," which took 32 hours to make the first trip up the Hudson from New York to Albany, to the great German liner "Imperator," with her vice admiral, 4 captains, erew of 1,000 men in an enormous hull 918 foet long, 98 foot beam, 57,000 tons displacement on load draft, propelled by turbines of about 65,000 horsepower, combining speed with the most luxurious appointpower, combining speed with the most luxurious appoint-
ments and conveniences for her passengers, is the progress of merchant marine.

From Perry's flagship, the "Niagara," built of green lumber, with her primitive armament, to the 30,000 ton modern battleship with her battery of 12-ineh guns, and protected by the best steel armor from 12 to 18 inches thick, is the story of the wonderful achievement of naval engineering of a century.

The young man who decides to take up marine engineerring as a profession will find it most fascinating in either of its braches, hull design or propelling equipment and auxiliaries. So many beautiful engineering problem to work out, and such a variety-no two jobs alike-all vessels designed to meet the special requirements under which they are to operate.

First there is the fresh and salt water classification, the deep draft and.light draft type, the latter in use on shallow lakes and rivers, and usually of the side or stern wheel types. These are seen on the Ohio and Mississippi rivers. Many of this type have been built in the United States for South America, such as the steamer "Mamore." There have recently been built at Port Arthur, on Lake Superior, two very fine steamers of this class, to ply on the Kootenay Lakes of British Columbia. These boat run on a draft of 4 feet six inches and make 22 miles an hour propelled by light tandem compound engines working under 200 pounds pressure per square inch, and developing 1,200 horse-power. A unique feature in the construction of these boats is the fact that they were completely built at Port Arthur, and then shipped in a knocked down condition by rail to Nelson, B. C. The first of these steamers is the "Nasookin," 227 feet over all, 40 feet beam, 8 feet deep.

The stern wheeler lends itself particularly to shallow lakes or rivers because it can be so easily steered. Usually it has two rudders, and the flow of water from the wheel against the port or starboard rudder alternately, causes the boat to come about very quickly.

Before the type of a ship can be determined, there are many preliminary investigations to be considered. The boat must be designed to especially meet the conditions of her trade. The owner or manager usually knows his own business, and can be of great assistance to the naval architect or designer in deciding the best arrangement of cabins, cargo space, carrying capacity, draft, etc., and the most desirable machinery.

Then there is always the business side to be considered. Though an undertaking may be à complete engineering success, if the financial part is not satisfactory, there i small credit for the engineering end. It may have failed through lack of proper supervision in the shop or on the field, or it may have been that the designs were expensive from a machine shop point of view. A little more consideration in the drafting room might have saved the profit.

Among the most prized possessions of engineers are their private note books. Text books and treatises are great helps to them but the personal notes and sketches of good details, the results of personal experiences jotted down from time to time, also well tried formulm and results of tests that they have from their own knowledg secured and know can be depended upon, are of the greatest value.

The marine engineer must have a good idea of electrical engineering, as this equipment is becoming more and more of a necessity on shipboard and is likely soon to be used on all auxiliary machinery. The electrical apparatus on warships and big liners is enormous, th cost of electrical equipment on one of our latest battleships was $\$ 300,000$.

Ship ventilation is being widely used. Refrigeration has become another important feature in the equipment of vessels. All passenger steamers and the better class of freighters have their own refrigerating plants. Re frigeration has revolutionized the method of carryin perishable goods such as beef and fruit. Steamer especially designed for this trade are marvels of engineering skill. Sanitary and hydraulic engineering figure largely in the design of a modern passenger teamer.

The Diesel oil engine, or the internal combustion motor, has opened up a new and interesting field for the marine engineer. While so far, not very much has been accomplished in this country, a great industry has been developed abroad, and a large fleet of Diesel propelled vessels are in the commerce of the world. Tankers up to 15,000 tons displacement are being built with this type of motor, as well as some German warships. At present there are but two of any size being operated on the great lakes, the "Calgary," of about 700 horsepower, and the "Fordonian," of 900 horse-power, both of these are foreign constructed vessels and Canadian bottoms.

The chief difficulty for the Diesel motor in the United States, where coal for marine purposes is so cheap, is the uncertain supply of crude oil or petroleum which cannot at present be satisfactorily or regularly procured at a reasonable price. If this were not so, I can see no reason why this method of propulsion would not rapidly supercede the present steam engine. The principal advantage being economy in operation as regards the amount of fuel consumed which is only about four tenths of a pound per horse-power, while the coal consumption is from one and a half to two pounds. A smaller engineering force, the weight and space gained by doing away with the boilers and coal bunkers, convenience of fueling as it requires no trimming, the radius of steaming under one fueling, the saving of fuel while the vessel is in port and many other advantages that might be mentioned.

So the young man who thinks of undertaking either branch of the profession of marine engineering and ship building will find he has to have a good broad education and a good general knowledge of many of the branches of engineering.

I have always contended that the finished marine engineer could, with a little preparation, undertake most of the other branches such as civil, hydraulic, electric and others, because of the elasticity of mind required to meet the diversified problems that come up in many years experience in the ship yard and shops.

The opportunities in this country for the marine engineer are many. If he wishes to follow the profession of a designer, he will find ship yards of more or less importance on nearly all the rivers and lakes from Maine to California. If he wishes to follow the sea, there was probably never a greater demand for young men of education than now. On our own lakes good men are needed. The old type of engineer is fast becoming a thing of the past and our big steamship companies are looking for men of engineering education. They find it pays to have their investment in the hands of men who understand the theory of it all, as well as the practical end. Some of them have established winter classes for the betterment of their men.

The remuneration for this type of men is very good, and exceeds the average office man by far.

In conclusion, let me emphasize the importance of having at least most of the qualifications that have been spoken of in this article. Unless you are a born engineer, you are not likely to be a success as I have been taught to measure success.

\section{A Novel High-Tension Voltmeter}

According to the Elektrotechnische Anzeiger, as quoted in Die Umschau, the firm of. Siemens and Halske has patented.a high tension voltmeter which makes use of thiat peculiar phenomenon of electrostatics which is known as the electric wind. This phenomenon is usually exhibited with the aid of the electric vane shown in Fig. 1. A vertical metal rod, bearing at its top three or more horizontal spokes with their pointed tips bent a right angles; and all turned in the same rotational direction, is mounted on an insulated tripod in a socket which allows it to rotate with little friction. When the socket is connected with an electrical source of high potential, such as an induction coil or a static electrical machine in operation, the vane is set into rapid rotation, in the direction opposite to that in which the spokes are bent, as is indicated by the arrows in Fig. 1.

The following explanation of this phenomenon is given by J. J. Thomson. Air and other gases possess ver little electrical conductivity, so that the production of an appreciable current requires a very high tension. In these conditions the ions, which are the carriers of the electricity, attain so great a velocity that they shatter the molecules with which they collide, and thus produce

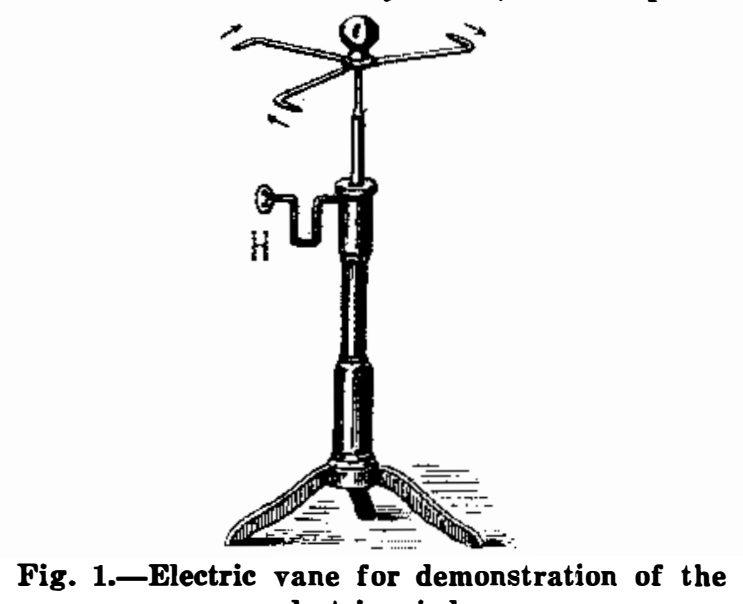

electric wind. new ions. When a great many ions have been produced, a discharge takes place at sharp points of the charged conductor. This brush discharge, as it is called, is visible in the form of a sheaf of luminous rays of measurable length. At the end of the brush is an accumulation of ions, which, being repelled by the electrified point, set the surrounding air in motion, and thus produce the electric wind. The resulting reaction drives the conductor, if it is movable, in the opposite direction.

-The designation electric wind implies that the discharge acts like a stream of air expelled from the electrifed point. If tobacco smoke is blown against a sharp point connected with the conductor of an electrical machine, the smoke is carried away by the electric wind. The flame of a candle, held near the point, is blown over (Fig. 2), and the pressure of the electric wind can be felt by the hand. These facts indicate that the electric wind possesses a high velocity. M. Holtz, the inventor of the static induction machine which bears his name, measured the deviation of a vertical plate suspended athwart the air current, and deduced a velocity of about 